\title{
Gambaran Pola Asuh Psikososial Anak Stunting dan Anak Normal di Wilayah Lokus Stunting Kabupaten Pasaman dan Pasaman Barat Sumatera Barat
}

Masrul

\section{Abstrak}

Stunting mempengaruhi sekitar seperempat anak di bawah lima tahun di seluruh dunia. Kondisi sistemik kekurangan gizi kronik merupakan dampak dari stunting. Terdapat 7,6 juta (37\%) anak Indonesia menderita stunting dan 46,1\% angka penderita stunting di Sumatera Barat, angka ini sudah mengalami penurunan pada tahun 2018 sebesar 40,8\%. Jumlah itu menunjukkan banyak anak-anak yang membutuhkan perhatian lebih, karena mereka tidak tumbuh dengan baik. Program intervensi nutrisi yang telah berjalan selama ini belum mampu secara optimal memperbaiki kondisi anak stunting. Tujuan penelitian ini adalah menentukan profil pola asuh stimulasi psikososial anak stunting dan perbedaan dengan anak normal di wilayah lokus stunting Kabupaten Pasaman dan Pasaman Barat. Desain penelitian ini berupa penelitian kuantitatif menggunakan desain cross sectional. Penelitian ini dilakukan pada 185 anak usia 0-3 tahun, terdiri dari 94 responden kelompok stunting dan 91 responden kelompok tidak stunting. Penelitian ini dilakukan melalui beberapa tahap, yaitu pengumpulan data menggunakan kuesioner dan instrument HOME. Dari penelitian ini diketahui hampir semua sub indikator memperlihatkan keadaan yang masih kurang; pola asuh stimulasi psikososial masih kurang; tingkat sosial ekonomi kehidupan anak stunting lebih rendah daripada anak normal. Diharapkan di masa depan dapat dilakukan pencegahan terjadinya intrautrin dengan menjaga serta pola asuh terutama pola asuh psikososial yang optimal dari keluarga.

Kata kunci: stunting, lokus stunting, pola asuh psikososial

\begin{abstract}
Stunting affects about a quarter of children under five years old worldwide. The systemic condition of chronic malnutrition is the effect of stunting. There are 7.6 million (37\%) Indonesian children suffering from stunting and $46.1 \%$ of the number of stunting patients in West Sumatra, this number has decreased in 2018 by $40.8 \%$. That number shows that many children need more attention because they don't grow well. The nutrition intervention program that has been running so far be able to optimally improve the condition of stunting children. The objective of this study was to determine the profile of parenting psychosocial stimulation of stunting children and differences with normal children in the stunting locus of Pasaman and West Pasaman Regency. The design of this study was quantitative research using a cross-sectional design. This study was conducted in 185 children aged 0-3 years, consisting of 94 respondents in the stunting group and 91 respondents in the non-stunting group. This research was conducted through several stages, namely data collection using questionnaires and HOME instruments. From this study it was known that almost all subindicators show a condition that is still lacking; parenting psychosocial stimulation is still lacking; the socioeconomic level of life for stunting children is lower than for normal children. It is expected that in the future prevention of intrauterine can be done by maintaining and parenting especially optimal psychosocial parenting from the family.
\end{abstract}

Keywords: stunting, stunting locus, psychosocial parenting

Affiliasi penulis: Bagian IImu Gizi Fakultas Kedokteran Universitas Andalas Padang
Korespondensi: Jl. Perintis Kemerdekaan No. 94 Padang Email: masrul@med.unand.ac.id Hp: +62 81363152961 


\section{PENDAHULUAN}

Stunting merupakan dampak dari kondisi sistemik kekurangan gizi kronik dan mempengaruhi sekitar seperempat anak di bawah lima tahun di seluruh dunia. Stunting pada anak dapat berkembang selama dua tahun pertama kehidupan dan sebagian besar disebabkan oleh kekurangan nutrisi dan penyakit menular ${ }^{1}$. Pada tahun 2014, diperkirakan ada 159 juta anak stunting yang hampir semuanya tinggal di negara berpenghasilan rendah ${ }^{2,3}$. Data Kementrian Kesehatan RI tahun 2013 melaporkan anak Indonesia menderita stunting sebanyak 7,6 juta $(37 \%)^{4}$. Angka penderita stunting di Sumatera Barat berada di atas angka nasional yaitu 46,1\%. Angka ini sudah mengalami penurun menjadi 40,8\% pada tahun 2018 Jumlah itu menunjukkan banyak anak-anak yang membutuhkan perhatian lebih, karena mereka tidak tumbuh dengan baik ${ }^{4,5}$.

Stunting memberikan efek jangka panjang seperti kelangsungan hidup yang menurun, perkembangan kognitif dan motorik yang terganggu, produktivitas ekonomi yang menurun, dan kesempatan untuk hidup dalam kemiskinan yang lebih tinggi di masa dewasa ${ }^{1,6}$. WHO telah menetapkan target pengurangan secara global sebesar $40 \%$ jumlah anak balita stunted pada tahun $2025^{7}$. Pengurangan anak yang stunted ini masuk dalam United Nations Sustainable Development Goal ${ }^{8}$.

Program intervensi nutrisi yang telah berjalan selama ini belum mampu secara optimal memperbaiki kondisi anak stunting. Hasil pengamatan, analisis dan pemodelan program intervensi nutrisi dari 34 negara menunjukkan bahwa pelaksanaan 10 evidence-based nutritional interventions yaitu suplementasi asam folat, suplementasi protein seimbang untuk ibu, suplementasi kalsium untuk ibu, multiple suplentasi micronutrient selama kehamilan, promosi menyusui, pemberian makanan tambahan yang cukup, pemberian vitamin $\mathrm{A}$ dan suplementasi zinc dengan tingkat cakupan $90 \%$ hasilnya hanya mampu menekan angka stunting sebesar $15 \%{ }^{9}$. Angka ini jauh dari tujuan Internasional untuk mengurangi stunting.

Praktek asuhan psikososial didefinisikan sebagai perilaku yang dipraktekkan oleh pengasuh (ibu, bapak, nenek, atau orang lain) dalam memberikan stimulus dan dukungan emosional yang dibutuhkan anak untuk proses tumbuh kembang ${ }^{10}$.

Penelitian ini merupakan salah satu bagian dari penelitian besar tentang paket Intervensi masalah gizi dan penerapan 1000 hari pertama kehidupan di daerah lokus stunting di Kabupaten Pasaman dan Pasaman Barat provinsi Sumatera Barat melalui kerjasama antara Direktorat Gizi Masyarakat Kementrian Kesehatan RI dan Fakultas Kedokteran Universitas Andalas pada tahun 2018 dengan nomor kontrak KN01.01/2/1302/2018 dan 2655/UN.16.2/TU/ 2018 tanggal 6 bulan April tahun 2018.

Tujuan penelitian ini adalah mengetahui profil pola asuh stimulasi psikososial anak stunting dan perbedaan dengan anak normal di wilayah lokus stunting Kabupaten Pasaman dan Pasaman Barat

\section{METODE}

Jenis penelitian ini adalah penelitian kuantitatif menggunakan desain cross sectional, Data tentang variabel independen dan variabel dependen dikumpulkan dan dinilai pada suatu waktu. Penelitian ini dilakukan pada 185 anak usia 0-3 tahun, terdiri dari 94 responden kelompok stunting dan 91 responden kelompok tidak stunting.

Pengumpulan data pola asuh psikososial menggunakan instrument HOME. Data dikumpulkan oleh tenaga DIII Gizi yang sudah dilatih sebelumnya.

\section{HASIL}

\section{Karakteristik Responden}

Karakteristik responden dalam penelitian ini dapat diketahui sebagai berikut. 
Tabel 1. Karakteristik anak

\begin{tabular}{|c|c|c|c|}
\hline \multirow[b]{2}{*}{ Variabel } & \multicolumn{2}{|c|}{ Status Gizi } & \multirow[b]{2}{*}{$\mathbf{p}$} \\
\hline & $\begin{array}{c}\text { Stunting } \\
(\mathrm{n}=94)\end{array}$ & $\begin{array}{c}\text { Normal } \\
(n=91)\end{array}$ & \\
\hline \multicolumn{4}{|l|}{ Jenis kelamin } \\
\hline - laki-laki & 50 & 42 & 0.418 \\
\hline - perempuan & 44 & 49 & \\
\hline Umur anak & 23.97 & 24.44 & 0.640 \\
\hline (bulan), & \pm & \pm & \\
\hline rerata $\pm S D$ & 6.74 & 6.95 & \\
\hline Berat badan & 3284.04 & 3210.88 & 0.301 \\
\hline lahir bayi & \pm & \pm & \\
\hline $\begin{array}{l}\text { (gram), } \\
\text { rerata } \pm S D\end{array}$ & 480.65 & 478.83 & \\
\hline Panjang & 41.54 & 46.93 & $0.007^{*}$ \\
\hline badan lahir & \pm & \pm & \\
\hline $\begin{array}{l}\text { bayi }(\mathrm{cm}) \text {, } \\
\text { rerata } \pm S D\end{array}$ & 16.80 & 8.85 & \\
\hline Anak ke, & 2.56 & 2.60 & 0.854 \\
\hline \multirow[t]{2}{*}{ rerata $\pm S D$} & \pm & \pm & \\
\hline & 1.54 & 1.44 & \\
\hline
\end{tabular}

Tabel 1 berdasarkan karakteristik anak diketahui bahwa terdapat hubungan panjang badan lahir bayi dengan kejadian stunting $(p<0.05)$. Namun tidak terdapat hubungan jenis kelamin, umur, berat badan lahir, urutan kelahiran anak dengan kejadian stunting $(p>0.05)$.

\section{Sumber Daya Manusia Yang Mengasuh}

Sumber daya manusia yang mengasuh dapat dilihat pada Tabel 2 berikut.

Tabel 2 diketahui terdapat hubungan adanya SDM yang menggantikan pekerjaan rumah tangga dengan kejadian stunting $(p<0.05)$. Namun tidak terdapat hubungan SDM yang sering mengasuh, SDM pengganti bila ibu tidak ada dan keterlibatan suami dengan kejadian stunting.
Tabel 2. Sumber daya manusia yang mengasuh

\begin{tabular}{|c|c|c|c|}
\hline \multirow[b]{2}{*}{ Variabel } & \multicolumn{2}{|c|}{ Status Gizi } & \multirow[b]{2}{*}{ p } \\
\hline & $\begin{array}{l}\text { Stunting } \\
(\mathrm{n}=94)\end{array}$ & $\begin{array}{l}\text { Normal } \\
(n=91)\end{array}$ & \\
\hline \multicolumn{4}{|l|}{$\begin{array}{l}\text { SDM yang sering } \\
\text { mengasuh }\end{array}$} \\
\hline Ibu & $90(95.7)$ & $85(93.4)$ & $\mathrm{N} / \mathrm{A}$ \\
\hline Suami & $1(1.1)$ & 0 & \\
\hline $\begin{array}{l}\text { Nenek/kakek dari } \\
\text { anak }\end{array}$ & $3(3.2)$ & $5(5.5)$ & \\
\hline $\begin{array}{l}\text { Anak ibu yang belum } \\
\text { dewasa }\end{array}$ & 0 & $1(1.1)$ & \\
\hline \multicolumn{4}{|l|}{$\begin{array}{l}\text { SDM yang } \\
\text { menggantikan ibu bila } \\
\text { tidak ada }\end{array}$} \\
\hline Suami & $19(20.2)$ & $29(31.9)$ & 0.101 \\
\hline $\begin{array}{l}\text { Nenek/kakek dari } \\
\text { anak }\end{array}$ & $34(36.2)$ & $29(31.9)$ & \\
\hline Adik/kakak ibu & $4(4.3)$ & $8(8.8)$ & \\
\hline $\begin{array}{l}\text { Anak ibu yang } \\
\text { berusia >15 tahun }\end{array}$ & $1(1.1)$ & $3(3.3)$ & \\
\hline $\begin{array}{l}\text { Anak yang belum } \\
\text { dewasa }\end{array}$ & $7(7.4)$ & $7(7.7)$ & \\
\hline dan lain-lain & $29(30.9)$ & $15(16.5)$ & \\
\hline $\begin{array}{l}\text { SDM yang } \\
\text { menggantikan } \\
\text { pekerjaan rumah } \\
\text { tangga }\end{array}$ & & & \\
\hline Ada & $30(31.9)$ & $46(50.5)$ & $0.015^{*}$ \\
\hline Tidak ada & $64(68.1)$ & $45(49.5)$ & \\
\hline \multicolumn{4}{|l|}{ Keterlibatan suami } \\
\hline Tidak ikut & $10(10.6)$ & $11(12.1)$ & 0.729 \\
\hline $\begin{array}{l}\text { Dalam waktu tertentu } \\
\text { saja }\end{array}$ & $64(68.1)$ & $59(64.8)$ & \\
\hline Punya peran besar & $19(20.2)$ & $21(23.1)$ & \\
\hline dan lain-lain & $1(1.1)$ & 0 & \\
\hline
\end{tabular}




\section{Pola Asuh Psikososial}

Tabel 3. Distribusi rerata nilai sub indikator HOME

\begin{tabular}{lcc}
\hline \multirow{1}{*}{ Variabel } & \multicolumn{2}{c}{ Status Gizi } \\
\cline { 2 - 3 } & $\begin{array}{c}\text { Stunting } \\
(\mathbf{n}=94) \\
\text { Rerata } \pm \text { SD }\end{array}$ & $\begin{array}{c}\text { Normal } \\
(\mathbf{n}=\mathbf{9 1}) \\
\text { Rerata } \pm \text { SD }\end{array}$ \\
\hline $\begin{array}{l}\text { Responsif orang tua } \\
\text { terhadap emosional dan } \\
\text { verbal anak }\end{array}$ & $8.10 \pm 2.190$ & $8.56 \pm 1.951$ \\
$\begin{array}{l}\text { Menerima terhadap } \\
\text { prilaku anak }\end{array}$ & $1.59 \pm 1.432$ & $1.48 \pm 1.486$ \\
$\begin{array}{l}\text { Pengaturan fisik } \\
\text { lingkungan anak }\end{array}$ & $3.38 \pm 1.262$ & $3.47 \pm 1.250$ \\
$\begin{array}{l}\text { Penyediaan alat } \\
\text { permainan anak yang } \\
\text { memadai }\end{array}$ & $4.87 \pm 2.498$ & $5.10 \pm 2.665$ \\
$\begin{array}{l}\text { Keterlibatan ibu dengan } \\
\text { anak }\end{array}$ & $3.74 \pm 1.026$ & $3.85 \pm 1.053$ \\
$\begin{array}{l}\text { Memberikan kesempatan } \\
\text { stimulasi bervariasi setiap } \\
\text { hari } \\
\text { Skor Total HOME }\end{array}$ & $2.28 \pm 1.239$ & $2.26 \pm 1.134$ \\
\hline & $24.34 \pm 6.829$ & $25.03 \pm 6.158$ \\
\hline
\end{tabular}

Tabel 3 diketahui skor total instrument HOME tidak terlalu jauh antara anak stunting dan anak normal. Masih rendahnya pola asuh psikososial yang baik antara anak stunting dengan anak normal. Hampir semua sub indikator memperlihatkan keadaan yang masih kurang.

Tabel 4. Gambaran pola asuh psikososial

\begin{tabular}{lccc}
\hline \multirow{2}{*}{ Variabel } & \multicolumn{2}{c}{ Status Gizi } & \multirow{2}{*}{$\mathbf{p}$} \\
\cline { 2 - 3 } & $\begin{array}{c}\text { Stunting } \\
(\mathbf{n}=\mathbf{9 4})\end{array}$ & $\begin{array}{c}\text { Normal } \\
(\mathbf{n = 9 1 )}\end{array}$ & \\
\hline $\begin{array}{l}\text { Kategori Pola Asuh } \\
\text { Psikososial }\end{array}$ & & & 0.765 \\
Rendah & $58(61.7)$ & $52(57.1)$ & \\
Sedang & $34(36.2)$ & $36(39.6)$ & \\
Baik & $2(2.1)$ & $3(3.3)$ & \\
\hline
\end{tabular}

Tabel 4 diketahui masih rendahnya pola asuh psikososial yang baik antara anak stunting dengan anak normal.

\section{PEMBAHASAN}

\section{Sumber Daya Manusia Yang Mengasuh}

Sebagian besar pengasuh utama adalah ibu, baik pada anak normal maupun anak stunting. Suami cukup berperan menggantikan pengasuhan bila ibu berhalangan pada anak normal dibanding dengan anak stunting. Pada anak normal tersedia tenaga pengganti pekerjaan rumah tangga ibu dibandingkan dengan anak stunting. Sumber daya pengasuhan, tenaga pengganti pekerjaan ibu merupakan faktor penting dalam proses tumbuh kembang anak ${ }^{11}$.

Menurut konsep Engle (1992) sumber daya pengasuhan merupakan faktor penyebab dasar yang berperan secara tidak langsung terhadap pertumbuhan-perkembangan bayi.faktor ini terlebih dahulu mempengaruhi praktek asuh dan kemudian praktek asuh mempengaruhi asupan zat gizi dan kesakitan bayi, terakhir baru ke pertumbuhan dan perkembangan bayi ${ }^{12}$.

Dari penelitian ini ditemukan dukungan suami dalam pengasuhan antara kedua kelompok anak ini tidak jauh berbeda. Namun pengganti pekerjaan ibu sangat penting untuk tumbuh kembang anak ${ }^{11}$.

\section{Pola Asuh Psikososial}

Pengukuran dengan HOME terhadap stimulasi psikososial anak relatif masih kurang dari normal dengan skor <40. Hampir semua sub indikator memperlihatkan keadaan yang masih kurang. Hasil dari pengamatan terstruktur oleh dokter ahli jiwa anak sebanyak 15 orang sampel hubungan ibu dan anak di sana juga memperlihatkan kurangnya interaksi dan stimulasi ibu.

Hasil penelitian Mc Gregor di Guatemala 1987, memperlihatkan hasil stimulasi yang memadai cukup besar manfaatnya untuk tumbuh kembang anak ${ }^{6,13}$. Rendahnya stimulus psikososial tentu memberi dampak terhadap pertumbuhan anak mereka.

Secara teoritis stimulasi psikososial yang baik dapat meningkatkan interaksi ibu dengan bayi dan proses skin to skin contact. Kedua proses ini dapat meningkatkan sistim imunitas bayi dan proses metabolisme menjadi normal. Namun dari hasil penelitian ini walaupun dari proporsi berbeda antara aanak stunting dan anak normal namun secara statistic tidak terlalu berbeda secara signifikan ${ }^{14}$.

\section{SIMPULAN}

Sebagian besar pengasuh utama adalah ibu, baik pada anak normal maupun anak stunting. Suami cukup berperan menggantikan pengasuhan bila ibu 
berhalangan pada anak normal dibanding dengan anak stunting. Pengganti pekerjaan ibu selama mengasuh sangat penting. Hampir semua sub indikator memperlihatkan keadaan yang masih kurang dari setiap sub indikator. Pola asuh stimulasi psikososial anak stunting dan anak normal masih kurang baik.

\section{DAFTAR PUSTAKA}

1. Black RE, Victora CG, Walker SP. Maternal and child undernutrition and overweight in low -income and middle-income countries. Lancet. 2013; 382: 427-51.

2. Semba RD. Nutrition and development: a historical perspective. Dalam: Semba RD, Bloem MW, editor (penyunting). Nutrition and Health in Developing Countries. Edisi ke-2. Humana Press; Totowa NJ: 2008.hlm.1-31.

3. UNICEF/World Health Organization/World Bank Group . United Nations Children's Fund, World Health Organization, and World Bank Group. 2015. Levels and Trends in Child Malnutrition: Key Findings of the 2015 Edition.

4. Kementerian Kesehatan RI. Riset Kesehatan Dasar. Kemenkes RI; 2013.

5. Kementerian Kesehatan RI. Riset Kesehatan Dasar. Kemenkes RI; 2018.

6. McGregor SG, Cheung YB, Cueto S, Glewwe P, Richter L, Strupp B. The International Child
Development Steering Group. Developmental potential in the first 5 years for children in developing countries. Lancet. 2007; 369 (9555): 60-70.

7. de Onis M, Onyango A, Borghi E. Worldwide implementation of the WHO child growth standards. Public Health Nutr. 2012;15:1603-10.

8. Murray CJ. Shifting to sustainable development goals-implications for global health. N. Engl. J. Med. 2015;373:1390-3.

9. Bhutta ZA, Das JK, Rizvi A, et al. Evidence-based interventions for improvement of maternal and child nutrition: what can be done and at what cost? Lancet. 2013; 382:452-77.

10. Brooks J. The Process of Parenting. Yogyakarta: Pustaka Pelajar; 2011.

11. Engle PL, Menon P, Hadad L. Care and nutrition: concepts and measurements. Washington DC: FCND Discussion Paper No. 18; 1997.

12. Engle PL, 1992. Care and Child Nutrition. Paper for the International Nutrition Conference. New York: 1992.hlm.5-79.

13. Jalal F. Pengaruh gizi dan stimulasi psikososial terhadap pembentukan kecerdasan anak usia dini [artikel penelitian]. Padang: Universitas Andalas; 2008.

14. William CD, Baumslag N, Jellife DB, 1985. Mother and child helath delivering the service. London: Oxford University; 1985.hlm.100-23. 